\title{
GENE CONSERVATION PRACTICE AND PRODUCTION OF OLD HUNGARIAN GOOSE BREEDS
}

\author{
Bódi László ${ }^{1}$, Szalay István ${ }^{2}$, Thieu Ngoc Lan Phuong ${ }^{3}$
}

\begin{abstract}
Hungarian goose production and gene conservation practices have been a tradition in Hungary for several centuries. The old Hungarian geese can only be effectively maintained if the national programs can identify economic uses of the breed.
\end{abstract} This study aimed to examine the potential use of the Hungarian landrace goose (HL) either as a purebred or crossbred with the Hungarian Upgraded breed (HU). Crossbred offspring were produced by HL ganders and $H U$ layers, as egg production of HL layers is very low. Reproduction traits (egg production, fertility and hatchability) of parent stocks, body weight gain, feed consumption and slaughter values (slaughter loss, breast and thigh weight and proportions) and of offspring were measured. The results showed that fertility in the crossbred geese was insignificant compared to the fertility of $H L$ purebreds, while hatchability of crossbreds was higher than that of purebred HL or HU. $H L$ offspring had significantly lower body weight and weight gain, and a higher feed conversion rate than $H U$. The proportion of valuable meat parts (breast and thigh) was the highest in HU while weight in slaughter loss was also the highest in HU. In terms of body weight, feed conversion rate and slaughter properties, crossbred offspring showed intermediate inheritance. HL is recommended for crossbreeding with HU breeds and their offspring should be reared under

\footnotetext{
${ }^{1,3}$ Research Centre for Farm Animal Gene Conservation (HáGK), H-2100 Gödöllő, Isaszegi út 200., Hungary; Association for Hungarian Farm Animal Gene Conservation (MGE), H-2100 Gödöllő, Isaszegi út 208., Hungary

${ }^{2}$ Association for Hungarian Farm Animal Gene Conservation (MGE), H-2100 Gödöllő, Isaszegi út 208., Hungary

Email: bodi.laszlo@hagk.hu

Received date: $09^{\text {th }}$ May 2019; Revised date: $22^{\text {nd }}$ February 2019; Accepted date: $21^{\text {st }}$ August 2019
}

free-range keeping conditions.

Keywords: Hungarian goose, gene conservation, goose production.

\section{INTRODUCTION}

Since the climate of Hungary is very favorable for goose production, its practice has become a tradition spanning several centuries [1]. Hungarian goose production is typically export-oriented, as the sector produces internationally recognized high-value products which are significant to the national economy [2]. Hungary is one of the largest producers of geese in Europe [3], where according to [4], Hungary is the second largest producer of goose and duck foie gras, and is the biggest producer of goose fatty liver production [5], [6]. The data from the Hungarian Poultry Product Council [7], [8] shows that the export revenue from goose products increased by $44 \%$ from 2014 to 2016 . In 2016, the proportion of goose meat and liver from the countries whole poultry export was almost $20 \%$ demonstrates the economic importance of this sector. Previously, Hungarian breeder stocks were exported to Cuba in 1983, Russia (the former Soviet Union) in 1989, and China in 2005 [1], at present in Russia the Hungarian goose genotypes are still in high demand [9]. In Hungary, 22 genotypes- including meat and liver type breeds and hybrids - were recognized by the breeding authority in 2015 , and out of the 22 genotypes, 15 genotypes (68\%) were native Hungarian breeds [10]. This emphasizes the significance of domestic Hungarian goose breeding and goose gene conservation importance and traditions in Hungary. A white frizzled variety of the landrace Hungarian goose population has been maintained in its original form by the Debrecen University since 1975 [11]. A new gene 
conservation programme for the Hungarian goose was started by the Institute for Small Animal Research (presently the Research Centre for Farm Animal Gene Conservation HáGK), where growing populations of white, greyish and spotted color variants of frizzled goose collected from Transylvanian villages have been maintained [11]. Some new gene rescue programmes are being implemented to protect populations of geese such as the "Banat" Goose [12], "Garammenti" and "Lévai" Goose [13]. The origin of Hungarian geese date back to the Roman empire, when domestication of the greylag goose took place in the wet marshes in the Hungarian Great Plain of the Carpathian Basin. Over the centuries of farming practice, the breed became well adapted to the particular climate conditions of the country [14]-[16]. This study was conducted to examine the potential use of HL, either as purebred or cross-bred with HU.

\section{BACKGROUND}

\section{A. Frizzled Hungarian goose}

A unique variety of goose, called the frizzled Hungarian goose, used to commonly be found in a valley of the river Danube and around the coastline of the Black Sea. Frizzled feathers are caused by a mutant gene, an autosomal incomplete dominant single allele [14]-[16]. In homozygotes, the barbs are extremely curled so that no feather has a flat vane, heterozygotes are less extremely affected [16]. From the beginning of modern commercial goose breeding in Hungary, different color variants (white, greyish or spotted) were preferred not only for their excellent fatty liver quality, approved by all markets, but also for their meat quality which is present due to their foraging nature regardless of weather, and for their high-quality feather production [?], [14]-[16].

\section{B. Hungarian Landrace and Hungarian Up- graded Geese}

The Hungarian Upgraded (HU) goose breed was developed based on the Hungarian landrace (HL) goose - a type of utilization of HL. The breeding of white feathered stocks and selection of individual HL geese collected from the Great Hungarian Plain started in 1969 [17], in the Goose Breeding Research Station of the Gödöllő University of Agricultural Sciences (which later went on to become the Szent István University) in Babatpuszta. Different foreign breeds (mainly Embden) were used by small farms for increasing meat yield and reproduction traits (egg production) of Hungarian goose. According to [18], during the creation of founder stocks of the HU breed, the aim was to collect the most original Hungarian geese, despite their lower egg production. The HU was developed primarily by selection of reproductive traits within the HL breed. The results of this selective breeding programme was an average annual increase in egg production by $1 \mathrm{egg} / \mathrm{year}$, an average annual improvements in fertility by $1 \%$, an increased number of one-day-old goslings hatched per year, and increased meat production were observed in HU geese [17]. Main production characteristics of $\mathrm{HL}$ and HU geese are shown in Table 1.

Table 1: Production characteristics of Hungarian landrace (HL) and Hungarian Upgraded (HU) geese (adapted from [11])

\begin{tabular}{|l|l|c|c|}
\hline \multicolumn{2}{|c|}{ Traits } & HL & HU \\
\hline \multicolumn{2}{|l|}{ Egg production (year) per layer } & 15 & $45-50$ \\
\hline \multicolumn{2}{|l|}{ Egg fertility (\%) } & 65 & $85-90$ \\
\hline \multirow{2}{*}{ Mature body weight (kg) } & Male & $5.0-5.5$ & $6.0-6.5$ \\
\cline { 2 - 4 } & Female & $4.0-4.5$ & $5.5-6.0$ \\
\hline
\end{tabular}

The old Hungarian geese populations can only be maintained if the national programs can identify economic use of the breeds [19].

\section{MATERIALS AND METHODS}

\section{A. Experimental design}

A comparative study of HL, HU and the crossbreeds were carried out at the Institute for Small Animal Research (predecessor 
of HáGK), in Gödöllő. Crossbred offspring were produced by crossing HL ganders and $\mathrm{HU}$ layers. As the egg production of $\mathrm{HL}$ layers is very low, the reciprocal crossing between HL layers and HU ganders would not be practical or economical. No artificial insemination was used for producing experimental goslings. Their sex was checked after hatching and a permanent sign of sex was used (a cut on the finger-web) throughout the study. The purebred and crossbred goslings were raised under the same conditions. The experimental design is shown in Table 2.

Table 2: Experimental design

\begin{tabular}{|l|c|c|c|c|}
\hline \multicolumn{1}{|c|}{ Genotypes } & Labels & $\begin{array}{c}\text { Pens/ } \\
\text { genotype }\end{array}$ & $\begin{array}{c}\text { Males/ } \\
\text { pen }\end{array}$ & $\begin{array}{c}\text { Females/ } \\
\text { pen }\end{array}$ \\
\hline $\begin{array}{l}\text { Hungarian } \\
\text { landrace }\end{array}$ & HL & 3 & 25 & 25 \\
\hline $\begin{array}{l}\text { Hungarian } \\
\text { upgraded }\end{array}$ & HU & 3 & 25 & 25 \\
\hline $\begin{array}{l}\text { ơ Hungarian } \\
\text { landrace } \times \\
\text { कHungarian } \\
\text { upgraded }\end{array}$ & $\begin{array}{c}\mathrm{o}^{\mathrm{H}} \mathrm{HL} \\
\times \mathrm{HU}\end{array}$ & 3 & 25 & 25 \\
\hline
\end{tabular}

In the first 3 weeks, the geese were fed with a starter diet. The diet changed to grower in the 4th week after hatching and to goose life support feed in the 11th week. High-quality hay was also given to the youngsters as fibre consumption. Until 2 weeks of age, goslings were kept in caged conditions, from 2 to 8 weeks of age they could go to runner, and from 8 weeks of age, they were kept free-range with access to good quality pasture. Genotypes were kept separated, but the two sexes were kept together with a ratio of 1:1 (25 $\sigma^{7}$ and 25 o per pen). At 12 weeks of age, 8 males and 8 females which had the highest body weight were slaughtered from each genotype. Fertility and hatchability of eggs produced by parental $\mathrm{HL}$ and HU stock were investigated at the beginning of the experiment. Bodyweight, body gain weight and the feed conversion ratio (FCR) of offspring was checked every 2 weeks from birth. Slaughter weight loss, breast and thigh weight, and their proportions were measured at 12 weeks of age.

\section{B. Data analysis}

The data was processed with Microsoft Excel program, then analysed with ANOVA and T-test using SPSS software.

\section{RESULTS AND DISCUSSION}

Fertility and hatchability results are shown in Table 3, which shows that the HU breed significantly outperformed the HL. The fertility of eggs that was produced by the crossbreeding between HL ganders and HU layers, was comparable to that of HL layers. Hatchability of eggs produced from the crossbreeding between HL ganders and HU layers was considerably higher than eggs produced from purebred HU geese.

Table 3: Fertility and hatchability of eggs produced by Hungarian landrace (HL), Hungarian Upgraded (HU) and the cross between Hungarian landrace ganders and Hungarian Upgraded layers $\left(\sigma^{7} \mathrm{HL} \times\right.$ oHU)

\begin{tabular}{|l|c|c|c|}
\hline \multirow{2}{*}{ Genotype } & \multirow{2}{*}{$\begin{array}{c}\text { Fertility } \\
\text { \% }\end{array}$} & \multicolumn{2}{|c|}{ Hatchability } \\
\cline { 3 - 4 } & & $\begin{array}{c}\text { of } \\
\text { incubated eggs }\end{array}$ & $\begin{array}{c}\text { \% of } \\
\text { fertile eggs }\end{array}$ \\
\hline $\mathrm{HL}$ & 65.0 & 45.2 & 68.4 \\
\hline $\mathrm{o}^{\top} \mathrm{HL} \times$ \%HU & 67.8 & 61.2 & 91.1 \\
\hline $\mathrm{HU}$ & 84.9 & 73.8 & 86.8 \\
\hline
\end{tabular}

Comparing the two purebred breeds, it can be stated that the HL breed had significantly lower body weight and weight gain than HU. The weight of the crossbred offspring was close to the average of the offspring of the two breeds throughout the 22 week period. The difference in body weight between the two sexes of HL was higher than in the HU. Apparent sexual dimorphism was also 
reported in the weight of $\mathrm{HU}$ [20]. The sexual dimorphism displayed by the body weight of crossbreds was less than in HL, or even HU. Table 5 shows that there was no difference in FCR during the first 4 weeks. From the 4th week, the HU breed displayed the best results, and FCR of the HU and HL crossbreds was in-between. Better FCR was found in HU even though feed consumption of HU significantly exceeded HL. Bodyweight data is summarized in Table 4.

Besides live weight, the weight of valuable meat parts (breast and thigh) was the highest in the HU breed. However, the slaughter loss was also the highest in this breed, and the lowest in HL, although the difference between the genotypes was not substantial. Previously, Bleyer [21] had chosen the Szentes Nagyfehér (Golden Goose W) and Lippitsch genotypes which were specifically selected for meat production at 8 weeks of age, however, comparably the slaughter loss of those genotypes was essentially equal to the genotypes HL, HU and HL and the HU crossbreed. The proportion of valuable meat parts (breast and thigh) were the highest in the HU genotype. It significantly exceeded the results reported by Bódi [22]. Slaughter results are given in Table 6 .

\section{CONCLUSION}

In terms of weight and FCR, the advantage of $\mathrm{HU}$ is apparent, but the HL genotype resulted in better slaughter weight results, this demonstrates the economical usability of the breed. Body weight, FCR and slaughter properties expressed by crossbred offspring showed intermediate inheritance. In crossbreeds however, due to low egg production of the landrace Hungarian breed, HL can produce economically only as a male partner.

\section{ACKNOWLEDGMENT}

The research was carried out in the frame of the GAK öko_term (ALAP1-00123/2004) project, subsidized by National Research, Development and Innovation Fund (NKFIA).

\section{REFERENCES}

[1] Kozák J A. világ libahústermelésének és kereskedelmének alakulása az elmúlt évtizedekben (The development of goose production and trading in the world over the last decades). Gazdálkodás. 2012;56(6):512-521.

[2] Molnár Sz. Evaluation of the Hungarian and Polish goose meat production. Roczniki Naukowe Stowarzyszenia Ekonomistów Rolnictwa i Agrobiznesu. 2016;18(3):255-261.

[3] Rosiński A. Goose production in Poland and Eastern Europe. In: Buckland R, Guy G, editors. Goose production-FAO animal production and health paper. FAO UN; 2002. p. 124-137.

[4] Service Economie ITAVI. Situation de la production et du marché des palmipèdes à foie gras a l'automne; 2016.

[5] Kozák J. Production and market challenges of fattened liver. Animal welfare, ethology and housing systems. 2009;5(4):532-546.

[6] Kozák J. A hízott liba- és kacsamáj termelése, valamint piaci kihívásai (Production and market challenges of fatty goose and duck liver). Gazdálkodás. 2011;55(3):309-316.

[7] Látits M, Molnár Gy. A lúd ágazat eredményei és aktuális feladatai (Results and current challenges of goose sector); 2016.

[8] Látits M. Personal communication based of the data of Hungarian Poultry Product Council; 2017.

[9] BBJ HU. Hungarian company finds local partner for goose farm in Russian Federation Budapest Business Journal; 2015.

[10] Kozák J. Conditions for the recognition of Hungarianbred goose breeds. Hungarian Journal of Animal Production. 2015;64(2):141-150.

[11] Szalay I. Régi magyar baromfifajták. Old Hungarian Poultry. Budapest: Mezógazda Kiadó; 2002.

[12] Matiuti M. Indigenous and endangered domestic animal breeds and populations in Transylvania. Állattenyésztés és takarmányozás. 2010;59(2-3):87-95.

[13] Szalay I, Barta I, Emodi A, Koppany G, Lan Phuong TN, Dong Xuan KDT, et al. Gene rescue programme to protect local farm animal breeds and ecotypes in the Carpathian basin: "The gene ring" - "A géngyưrû". Scientific Journal of Tra Vinh Univeristy. 2018;1(32):39-48. DOI: 10.35382/18594816.1.32.2018.58.

[14] Szalay I. Traditional Hungarian poultry breeds Their use in sustainable agriculture. Hungarian Agricultural Research. 2018;11(32):15-19.

[15] Szalay I, Dong Xuan KDT. Old Hungarian poultry breeds and their use in high quality production. In: Proc. $1^{\text {st }}$ MGE-NEFE Workshop, NIAH Poultry Research Centre. Hanoi, Vietnam; 2007. p. 6-9.

[16] Szalay I. Régi magyar baromfifajták a XXI. In: században, editor. Old Hungarian Poultry in the $21^{\text {st }}$ century. Budapest: Mezőgazda Kiadó. Hanoi, Vietnam; 2015 . .

[17] Kozák J, Bódi L, Janan J, Ács I. Improvements in the reproductive characteristic of Hungarian Upgraded 
Table 4: Average body weight of Hungarian landrace (HL) and Hungarian Upgraded (HU) breeds during the 22-week rearing period

\begin{tabular}{|c|c|c|c|c|c|c|c|c|}
\hline \multirow{3}{*}{ Genotype } & \multirow{3}{*}{ Gender } & \multicolumn{7}{|c|}{ Average body weight, $\mathrm{g}$} \\
\hline & & \multirow{2}{*}{1 day old } & \multicolumn{6}{|c|}{ Age, weeks } \\
\hline & & & 4 & 8 & 12 & 16 & 20 & 22 \\
\hline \multirow{2}{*}{ HL } & $0^{7}$ & 81 & 1272 & 2884 & 3346 & 3770 & 4088 & 4174 \\
\hline & 우 & 82 & 1188 & 2460 & 2846 & 3220 & 3446 & 3509 \\
\hline \multirow{2}{*}{$\sigma^{\top} \mathrm{HL} \times$ \&HU } & $0^{7}$ & 86 & 1327 & 2910 & 3816 & 4004 & 4433 & 4735 \\
\hline & q & 87 & 1462 & 2776 & 3430 & 3602 & 3869 & 4135 \\
\hline \multirow{2}{*}{$\mathrm{HU}$} & $0^{x}$ & 91 & 1498 & 3298 & 4393 & 4848 & 5288 & 5450 \\
\hline & q & 88 & 1387 & 3104 & 3938 & 4271 & 4658 & 4804 \\
\hline
\end{tabular}

Table 5: Feed conversion ratio (FCR) in $\mathrm{kg}$ feed/kg body weight gain of experimental Hungarian landrace (HL), Hungarian Upgraded (HU) and their crossbreeds $\left(\sigma^{\top} \mathrm{HL} \times\right.$ QHU) in 4 different periods of rearing

\begin{tabular}{|c|c|c|c|}
\hline $\begin{array}{c}\text { Period, weeks } \\
\text { of age }\end{array}$ & HL & $\sigma^{\top} \mathbf{H L} \times$ \%U & HU \\
\hline $0-4$ & 2.1 & 2.0 & 2.1 \\
\hline $4-10$ & 3.8 & 4.4 & 4.5 \\
\hline $10-22$ & 18.9 & 23.7 & 24.0 \\
\hline $0-22$ & 5.5 & 6.0 & 6.3 \\
\hline
\end{tabular}

and Grey Landes geese in Hungary. World's Poultry Science Journal. 1997;53(2):197-201.

[18] Szélné SzM. Personal communication. In: The Poultry Site 2015 Global poultry trends - goose meat trade 'flat'. Hanoi, Vietnam; 1990.

[19] Szalay I, Bódi L, Kisné Do thi Dong Xuan, Szentes K, Barta I, Stompné MI, et al. Elaboration of the production system for special quality Hungaricum poultry products - summarised results of the project obtained in Godollo in 2006. A Baromfi. 2007;10(1):34-47.

[20] Bódi L, Ács I, Karsainé KM, Kozák J. Growth characteristics of Hungarian and Landes geese at age of 9 and 30 weeks. Állattenyésztés és Takarmányozás. 1993;42(6):533-540.

[21] Bleyer F. Szentesi nagyfehér, Lippitsch, Orosházi szürke és Kolos szürke lúd szülıpárok és utódaik teljesítményvizsgálatának eredményei. Budapest: Országos Mezőgazdasági Minôsítő Intézet; 1996.

[22] Bódi L. Effect of the year, age at slaughter, sex
Table 6: Slaughter results of male Hungarian landraces (HL), Hungarian Upgraded (HU) and their crossbreeds ( $\sigma^{\top} \mathrm{HL} \times$ \%HU) at 12 weeks of age

\begin{tabular}{|c|c|c|c|}
\hline Genotype & HL & $\sigma^{\top} \mathbf{H L} \times \wp \mathbf{H U}$ & HU \\
\hline Live weight (g) & 3867 & 4720 & 5087 \\
\hline Slaughter weight(g) & 2912 & 3539 & 3806 \\
\hline $\begin{array}{l}\text { Live weight/slaughter } \\
\text { weight }(\%)\end{array}$ & 75.3 & 75 & 74.8 \\
\hline Breast weight (g) & 922 & 1243 & 1370 \\
\hline Thigh weight, (g) & 729 & 786 & 870 \\
\hline $\begin{array}{l}\text { Breast and thigh weight/ } \\
\text { slaughter weight } \%\end{array}$ & 56.7 & 57.3 & 58.9 \\
\hline
\end{tabular}

and feather plucking on the carcass characteristics of Hungarian breed of geese. Állattenyésztés és Takarmányozás. 1994;43(6):517-523. 